\title{
The Challenge and Revolution Law Education is Faced with in the 'Internet Plus' Age
}

\author{
Hongfei Zhang ${ }^{1, a}$ \\ ${ }^{1}$ Faculty of Law, Nanchang Institute of Technology, Nanchang, China \\ ahanghongfei@nut.edu.cn
}

\begin{abstract}
With the constant development of information technology and the popularize of Internet, we entered the age of 'Internet Plus'. The key characteristic of this age is the combination of the Internet and traditional profession which curved out a new way and trend. So is education industry. To apply internet into the education process makes more possibility of teaching. And education structure changes too. In the age of 'Internet Plus', our country's law education is faced with challenges, and also new opportunities to develop on the contrary. This paper introduced the characteristics of 'internet plus', stated the challenges law education faced with, and proposed corresponding solutions.
\end{abstract}

Keywords: 'Internet Plus', law education, challenge, revolution

\section{INTRODUCTION}

The "Internet plus" action plan was put forward by premier Li Keqiang in his government working report in 2015. Afterwards, all walks of life realized that this plan would become the focus of future development. After this time, the Internet continues to integrate with traditional industries, bringing new development opportunities to traditional industries. The education industry, like other industries, is also integrated with the Internet, which makes the education industry inevitably affected by the Internet. Under such circumstances, how to adapt our law education to the requirements of the "Internet Plus" age and how to reform the teaching methods and educational ideas, and constantly improve the quality of law education has become an urgent problem for law educators[4].

\section{FIRST, THE CONNOTATION OF "INTERNET PLUS"}

"Internet plus" is an upgraded version of the integration of the two industries. It takes the Internet as the main content of the current information development and integrates useful information with industries such as industry, commerce and finance. But the most important thing in this process is to innovate, which is the real value of 'Plus'.It is in this way that "Internet plus" has become a new form of Internet development and promoted economic and social development. To put it simply, "Internet Plus" means "Internet + various traditional industries", but it is not simply the addition of the two, but the use of information technology on the network platform, combined with traditional industries, to create a new development path, to make $1+1>2$, in order to play out the true meaning of "Internet plus".

The most important feature of "Internet plus" is cross-border integration, openness, reform and innovation.Be brave to cross the boundary, and it will provide a solid foundation for innovation, integration and collaboration between industries, so as to make the intelligent group a reality. China's early mode of extensive resource-based growth is no longer applicable. We must find the right path through innovation-driven development, which is exactly the characteristic of 'Internet Plus'. We should carry out revolution with Internet based thinking and give full play to the power of innovation. Reshaping the structure is also an important feature of the times. Information globalization has broken the original social structure, economic structure and cultural structure, and the international discourse power is constantly changing. It is the brilliance of human nature that has been promoting the progress of science and technology, economic growth, social progress and cultural prosperity. The reason why the Internet is powerful is that it has the greatest respect for human nature, and it attaches great importance to the creation of human nature.For 'Internet Plus', ecology is a very important feature, because ecology itself is open. To promote the development of 'Internet plus', we need to remove some of the constraints of the past and connect those isolated innovations[1].

\section{SECOND, CHALLENGES OF LAW TEACHING IN THE AGE OF 'INTERNET PLUS'}

\subsection{Single Teaching Method}

The number of law school of our country and the number of undergraduate students is growing up. Law education quality goes up along with the increase in the number of masters and doctors of law, but failed to break through the barriers of law education. What improve most is the level of theory education, but for the cultivation of the students' vocational skills remains nearly the same. The Chinese government has issued some documents concerning the cultivation of law talents, all of which require that law education should meet the market demand and cultivate students' professional skills according to the characteristics of law profession. So that students can solve legal problems. Law vocational education not only needs to teach students basic legal knowledge, but also needs to train students' law practice skills. To impart 
basic legal knowledge to students is the basis of cultivating students' legal thinking and solving legal problems. However, China's law teaching is rigid and inflexible, which still adopts the way of teachers' active teaching and indoctrination, and students' passive learning and memory, which makes it difficult to exercise students' practical skills.

\subsection{Outdated Assessment Methods}

The assessment method of school plays a guiding role in students' learning. An effective assessment mechanism can improving the quality of law education, and stimulats students' learning motivation and enabling them to actively apply the theoretical knowledge they have learned into practice. At present, the law education in our country still use examination paper to assess students' learning. In this way, many students do not pay attention to their daily study and study hard when the final exam is approaching. Some teachers will give the key range to the students at the end of the exam. Students can get excellent results in the final exam only by learning the content within the range. The existence of this situation makes students do not really understand the content of learning, let alone the flexible use of knowledge. Now the country allows junior students to take the judicial examination, and many schools offer relevant courses for the judicial examination. These courses can not help students improve their legal level because the teaching content is designed for the examination[2].

\subsection{The Professional Construction is Limited}

Since China resumed the enrollment of higher education of law, the number of law school in our country has grown up more than 100 times with its development. Main reason of such fierce development is that construction demand of the law science is broad. As long as there is teacher who is able to teach a class in the school, you can open law professionals. There is no threshold requirement to law teachers in our country. It doesn't matter where the teacher is graduated from, as long as he or she has the teaching license, he or she can play the role of law teacher. In such a situation, many schools are short of teachers, and few teachers can cultivate students' practical ability, and schools do not have the corresponding practical teaching facilities. Only a very small number of schools have legal aid centers, and their application rate is extremely low. All sorts of reasons are mixed together, and that makes the students of law school lack practice opportunity. It is difficult to develop law professional skill. With the continuous development of society, the faculty of law school has been significantly improved, but many schools are still unable to support the practical education of law due to lack of funds[2].

\section{THIRD, REFORMATION METHODS OF LAW EDUCATION IN THE AGE OF 'INTERNET PLUS'}

\subsection{Determine the Training Program}

Law education should not merely indoctrinization law knowledge to students, but more importantly is to transmit leagal mind to students, which is an important step to cultivate citizens' legal consciousness. Nowadays, with the rapid development of China's economy and the rapid emergence of various new industries, a large number of law talents is in need. Take the financial industry as an example, it is an important development moment of economic globalization. China's foreign economic and trade are increasing. Among the large number of law school graduates, rare can understand economic trades. Once disputes arise, how to apply appropriate laws to safeguard rights and interests becomes an important issue. Therefore, when formulating the talent training objectives, the school should concern the actual needs of the society, cultivate talents in a diversified way, adapt to the new development form of the 'Internet Plus' age, make the Internet and legal professionals form a benign relationship, and promote the development of legal education through interaction[2].

\subsection{Reform the Teaching Model}

For law students, law knowledge is very important, but what is equally important is to make them develop legal mind. Compared with ordinary people, the biggest difference of legal professionals is their way of thinking. Legal personnel will summarize people's thinking according to the character of the law, and form a thinking pattern, which is affected by legal consciousness. The standard to distinguish legal talents from other talents is not whether they have legal knowledge, but whether they have professional legal thinking mode. Entering the 'Internet Plus' era, students can be exposed to more cases, which can effectively improve students' interest in learning and improve the quality of legal education. There are also many high-quality online course platforms. These courses are different from the contents and emphases of daily teaching, which can develop students' thinking and change the original indoctrination education method. This will help students minor in other subjects, improve their understanding of other fields and cultivate their legal thinking ability[1].

\subsection{Optimize the Assessment Methods}

After the students' career orientation is clarified, the course teaching method is reformed and the assessment method should be optimized scientifically and reasonably. 'Internet Plus' age can change the original rigid and inflexible assessment methods, and give full play to the advantages of big data. According to the knowledge taught, the teacher can create some virtual cases, find out the evidence materials of supporting cases through the network, and even inspect the students' teamwork ability and practical application ability through role exchange. This assessment process can enable 
students to think deeply and find out the applied legal norms, legal facts, legal relations and legal responsibilities gradually. It can also improve their application of legal thinking. Examine students' mastery of knowledge by case can also increase their interest in learning, enhance their legal thinking ability. From the aspect of law to regulate thinking direction and positioning, and to analysis of the problems and improve the processing capacity of their legal problems, comprehensively improve their professional quality. Thus to achieve the purpose of cultivating outstanding law talent.

\section{CONCLUSION}

To sum up, law education should not be one-way indoctrination, but two-way interaction. The realization of interactive education needs a certain opportunity, and the development of 'Internet Plus' offered it an opportunity. Rich Internet application data resources provide a good learning platform for students. Students can be very convenient to find the information they need, also can find the corresponding case resources, so that we can help them to deepen the understanding of law knowledge and to better apply law knowledge. It helps students form the legal thinking, improve their vocational skills, comprehensively improve their law quality, thus to achieve the purpose of cultivating outstanding legal person.

\section{REFERENCES}

[1] Cui yanfeng. Challenges and changes of legal education in the era of "Internet + " $[\mathrm{J}]$. Journal of northwest adult education college, 2018133, (1) : 57-61.

[2] Shi lei. Cultivation of legal thinking and reflection on legal education in the era of "Internet" [J]. Journal of jilin university of education, 2016,32, (10) : 119-122.

[3] Li minxiang. Study on challenges and changes of legal education in the era of "Internet +" [J]. Guide to family life, 2018, (7).

[4] $\mathrm{Wu}$ yalin. A brief analysis of challenges and changes faced by legal education in the era of "Internet + " [J]. Legal expo, 2018, (31) : 302-302.

[5] Wang xin. Dilemma and reform of legal education in the era of big data $[\mathrm{J}]$. Higher financial and economic education research, 2016,19, (4) : 76-79. 